GLOBAL JOURNAL OF SOCIAL SCIENCES VOL 19, 2020: 25-34

COPYRIGHT@ BACHUDO SCIENCE CO. LTD PRINTED IN NIGERIA. ISSN 1596-6216 www.globaljournalseries.com; Info@globaljournalseries.com

\title{
RELATIONSHIP BETWEEN CASH TRANSFER PROGRAMMES AND SCHOOL OUTCOMES IN AFRICA AND LATIN AMERICA: A SYSTEMATIC REVIEW
}

\section{JANE TEMIDAYO ABE AND OLADAYO NATHANIEL AWOJOBI}

(Received 4 November 2019, Revision Accepted 8 December 2019)

\begin{abstract}
Poverty is popularly believed to be a hindrance to schooling for children from poor households. To overcome this obstacle, cash transfers have been used to support and promote their access to education. This review assesses the effect of some cash transfers programmes in Africa and Latin America on children's educational outcomes. A systematic search for relevant studies was conducted online through google scholar. Inclusion criteria were met by ten studies- 5 in Africa and 5 in Latin America. Eight studies used a quantitative approach, while two adopted a mixed-methods technique. The included studies used different study designs, and their outcomes showed that both Conditional Cash Transfers (CCTs) and Unconditional Cash Transfers (UCTs) have positive effects on school outcomes. Some results showed strong evidence, others showed weak evidence while others showed limited evidence. Cash transfer programmes offer disadvantaged children the opportunity for schooling. However, the impact of these programmes varies because of their implementation designs.
\end{abstract}

KEYWORDS: Cash transfers, Children, Poverty, School

\section{INTRODUCTION}

The relationship between poverty and the lack of primary education is a research issue progressively more prevalent a few years ago (Mihai, Tiţan, \& Manea, 2015). Poverty makes people think of education failure, which indicates that children born into poverty are born in a vicious circle of poverty (Mihai et al., 2015). The negative impact of poverty on children is complicated, and it creates a variety of problems for children and their families (Child Fund International, 2013).

Poverty hinders children access to primary education, especially in developing countries.
Many families living in severe poverty conditions hardly can send one or all of their children to school (Mihai et al., 2015). For instance, in Zimbabwe, poverty constituted adverse effects on academic achievements of students from poor households (Moyo, 2013). Poor students were denied access from learning due to the inability of their parents to pay their school fees and students that dropped out of school did so because of lack of finance (Moyo, 2013). In another study conducted by Wikeley, Bullock, Muschamp \& Ridge (2007) which examined educational relationships of in-and-out of school activities and contrasted those experienced by children from poor households with a paired

Jane Temidayo Abe, Department of Psychology Nnamdi Azikiwe University Awka

Oladayo Nathaniel Awojobi, National Youth Council of Nigeria Lagos State Chapter

(C) 2020 Bachudo Science Co. Ltd. This work is licensed under Creative Commons Attribution 4.0 International license. 
sample of those in wealthy homes (Mihai et al., 2015). The study findings showed that children from poor households participated less in out-ofschool activities than their affluent peers (Mihai et al., 2015). Besides the fact that low-income families cannot cope with these financial limitations, there are also economic realities. Children must quit school to earn money to support their families (Mihai et al., 2015).

To address the growing poverty trend in developing countries, development and policymakers have increasingly adopted the use of cash transfer programmes as essential components of poverty eradication and social protection strategies (Barrientos, 2013; DFID, 2011; Hanlon, Barrientos, \& Hulme, 2010; Honorati, Gentilini, \& Yemtsov, 2015). Cash transfers are "set of public and private policies and programmes aimed at preventing, reducing and eliminating economic and social vulnerabilities to poverty and deprivation" (UNICEF-ESARO/Transfer Project, 2015: viii). Cash transfers support individuals who are poor to acquire necessities of life. Therefore, enhancing their short-term choices; with urgent demands better met, the conditions assigned to cash transfer programmes serve as incentives for poor households to aid the education and health of their children (Reimers, Da Silva, \& Treviño, 2006). For the longer-term, the emerging rise in the children's human capital development helps fight the intergenerational transmission of poverty (Reimers et al., 2006). Various sets of cash transfer programmes have become very much popular years back. Cash transfer programmes are now being used as essential social protection mechanisms to fight poverty. At the same time developing human and physical capital and sustaining vertical and horizontal equality (Slater \& Overseas Development Institute, 2008).

There is now a growing collection of peerreviewed and grey literature reviews concentrating on different outcomes and indicators on the impact of cash transfer programmes on their target groups. This review systematically assessed and synthesised some evidence from studies that assessed the effect of cash transfer programmes on school outcomes in Africa and Latin America.

\section{MATERIALS AND METHODS}

\section{Definition}

For this review, cash transfers refer to "all regular payments made to individuals and households to tackle poverty and vulnerability" (Independent Commission for Aid Impact, 2016). The World Bank also defined cash transfers as the provision of financial assistance to the poor or those to who are likely to fall below the poverty line in the absence of cash transfers (World Bank, 2011). Cash transfers include child-care grants, social pensions, unemployment benefits, cash for work programmes and other transfers to vulnerable people (independent Commission for Aid Impact, 2016). "Cash transfers can be conditional or unconditional" (Awojobi, 2018). When the provision of cash transfers is attached to compulsory behavioural obligations, they are conditional cash transfer programmes. These programmes work by giving cash payments to households only if they adhere to specific requirements, usually connected to health and education (de Janvry \& Sadoulet, 2006). For instance, various conditional cash transfer (CCT) programmes disburse benefits conditional on the purpose of preventive healthcare services, participation in health and nutrition education sessions planned to improve positive behavioural changes or school participation for school pupils or students (Barrientos \& DeJong, 2006; Lagarde, Haines, \& Palmer, 2007). Unconditional cash transfer (UCT) programmes are those in which households collect financial assistance because the households live in poverty, and there are no conditions attached to the transfer (Barrientos \& DeJong, 2006).

\footnotetext{
Criteria for considering studies for this review Types of studies

We examined all studies that met the inclusion criteria of the systematic review and examined their effects on the different range of outcomes. We included the following types of studies:

- quantitative descriptive,

- $\quad$ mixed methods,

- quasi-experimental,

- $\quad$ Randomised controlled trial.
} 
Types of participants

This review included children attending primary and secondary schools in Low-and-middle income countries. These children live in households that were considered poor because they lived below the national poverty line and cash transfers were given to these households to improve their human capital development.

\section{Types of interventions}

For interventions to be included in this review, they had to meet the following criteria:

- consist of money given to vulnerable households through electronic transfer, face-toface or mobile phone transfer;

- the transfer maybe conditional or unconditional with the primary aim to reduce poverty;

- provided by national governments through their agencies, non-governmental organisations or cash given to a target group for the case of scientific research;

- $\quad$ provided regularly;

- non-contributory cash transfers.

Types of outcomes measures

We included the following outcomes which we considered to the primary outcomes of the review:

$\begin{array}{ll}\text { - } & \text { school enrolment; } \\ \text { - } & \text { attendance; } \\ \text { - } & \text { sest score; } \\ \text { - } & \text { school completion; } \\ \text { - } & \text { progression. }\end{array}$

Search methods for identification of studies We conducted a literature search for relevant studies electronically through google scholar. The search focused on articles that mentioned phrases, such as cash transfers, cash transfer programmes, cash transfers and poverty reduction, poverty and education outcome, and cash transfers and school outcomes. The electronic search was limited to articles written in the English language, and we screened the titles and abstracts of the identified studies. We further searched reference citations of some articles identified online for publications that discussed the impact of cash transfers on school outcomes.

\section{Data collection and analysis Selection of studies}

From the online search that produced several articles, we excluded studies from Asia, Europe, Northern America and Oceania discussing the interface between cash transfers and school outcomes. To determine the relevance of the searched articles, we screened the titles and abstracts of studies that addressed the impact of cash transfers on school outcomes. Further to this, we included studies that evaluate the impact of cash transfers on various household outcomes that included educational outcomes. We excluded studies that did not comply with the inclusion criteria of the review.

\section{Data extraction}

This review systematically extracted the following information from the included studies and recorded them in a standard form:

$\begin{array}{ll}- & \text { Author names } \\ \text { - } & \text { Year of publication } \\ \text { - } & \text { Type of publication } \\ \text { - } & \text { Data collection method } \\ \text { - } & \text { Type of Intervention } \\ \text { - } & \text { Geographical location }\end{array}$

\section{Data synthesis}

Meta-analysis was not included in the review because the included studies differed in their study design, settings and outcomes. Therefore, a narrative synthesis was employed to present the similarities and differences between the findings of the included studies.

\section{RESULTS}

\section{Study selection}

The initial search for both peer-reviewed and grey literature based on titles produced 295 citations. Due to abstract, text and study outcomes screening, we excluded 215 articles leading to the retaining of 80 articles. An additional screening of the retained articles by full text led to the exclusion of 70 articles and the inclusion of 10 articles for the review. (Figure 1). 


\section{5 relevant articles identified through electronic search}

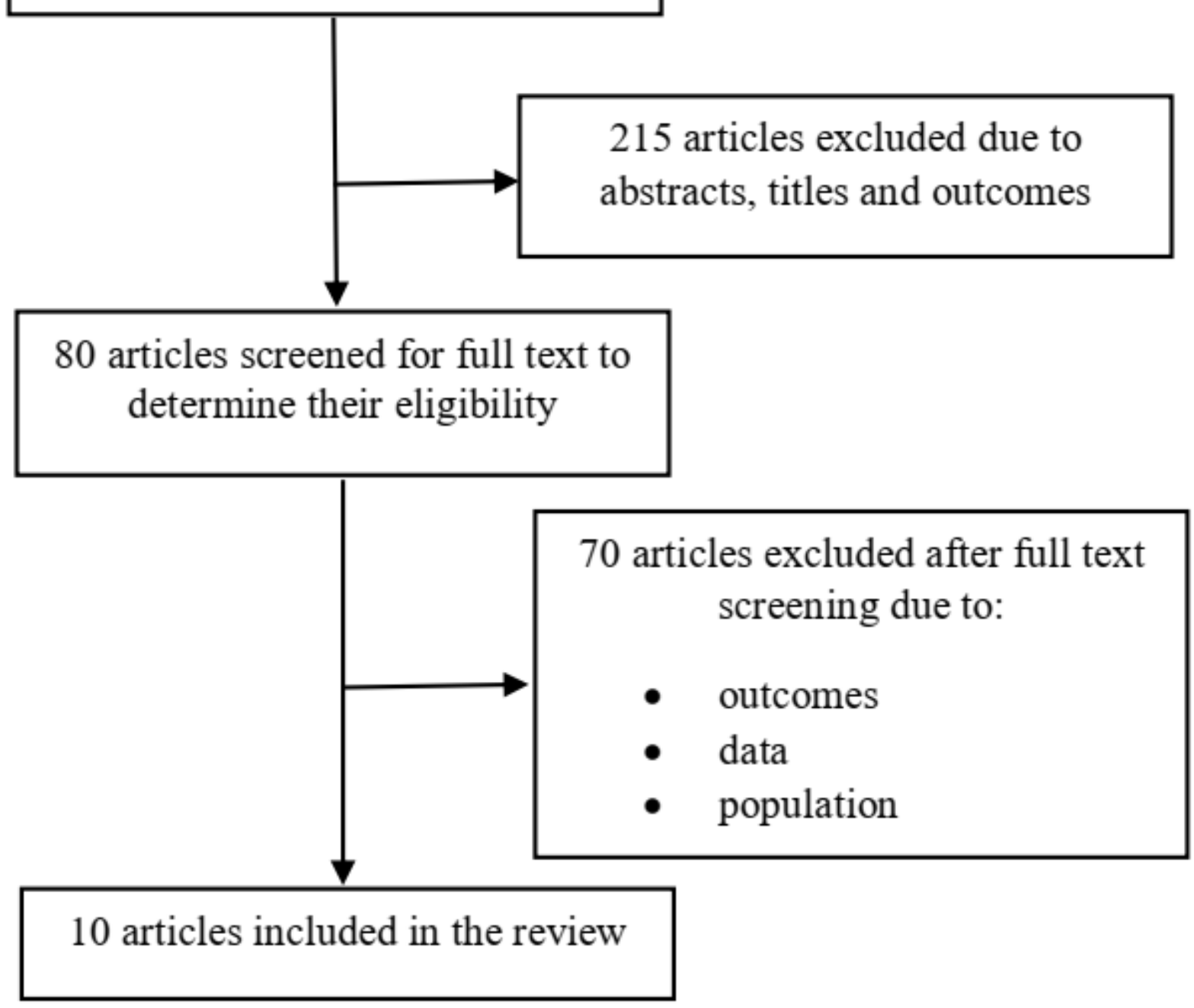

\section{Figure 1: Flow diagram showing study selection process}

\section{Study characteristics}

Five of the included studies were conducted in Africa and the other five in Latin America. The studies were published between the period of 2008 to 2017. In terms of methods adopted, eight of the studies used a quantitative approach, while the other two studies adopted a mixed-methods technique. Although some of the studies used more than one study designs, most of them used one study design each. CCT and UCT were the interventions examined by the included studies. Five studies examined the impact of CCT on school outcomes, four examined the impact of UCT on school outcomes, and the remaining one investigated both the impact of CCT and UCT on school outcomes. The primary outcomes measured by the reviewed studies include school enrolment, attendance, test scores, completion, and child labour. Table 1 illustrates the characteristics of the studies included. 
Table 1: Characteristics of included studies

\begin{tabular}{|c|c|c|c|c|c|}
\hline Study & Location & $\begin{array}{l}\text { Qualitative/ } \\
\text { Quantitative }\end{array}$ & Study design & Intervention & Main outcome measured \\
\hline Akreshet al. 2013 & Burkina Faso & Quantitative & $\begin{array}{l}\text { Randomized } \\
\text { Controlled } \\
\text { Trial (RCT) }\end{array}$ & CCT, UCT & $\begin{array}{l}\text { Enrolment, attendance, and } \\
\text { achievement test scores }\end{array}$ \\
\hline $\begin{array}{l}\text { Barrera-Osorio et al., } \\
2008\end{array}$ & Colombia & Quantitative & RCT & CCT & $\begin{array}{l}\text { Enrolment, attendance, } \\
\text { school completion, } \\
\text { expenditure, test score }\end{array}$ \\
\hline $\begin{array}{l}\text { Benhassine et al. } \\
2015\end{array}$ & Morocco & Quantitative & RCT & CCT & School participation \\
\hline Ham, 2014 & $\begin{array}{l}\text { Latin America } \\
\text { (Honduras, and } \\
\text { Mexico } \\
\text { Nicaragua) }\end{array}$ & Quantitative & $\begin{array}{l}\text { Quantitative } \\
\text { descriptive }\end{array}$ & CCT & Attendance, enrolment \\
\hline Handa et al. 2016 & Kenya & Quantitative & $\begin{array}{l}\text { A cluster } \\
\text { randomised } \\
\text { longitudinal } \\
\text { design }\end{array}$ & UCT & Enrolment \\
\hline Paredes, 2016 & Ecuador & Quantitative & $\begin{array}{l}\text { Quantitative } \\
\text { descriptive }\end{array}$ & UCT & Enrolment, completion \\
\hline Ribas et al, 2010 & Paraguay & Quantitative & $\begin{array}{l}\text { Non- } \\
\text { randomised }\end{array}$ & CCT & Attendance, progression \\
\hline Schaffland, 2012 & Brazil & Quantitative & $\begin{array}{l}\text { Quantitative } \\
\text { descriptive }\end{array}$ & CCT & Attendance, enrolment \\
\hline UNICEF, 2017 & Nigeria & Mixedmethods & $\begin{array}{l}\text { Quasi- } \\
\text { experimental }\end{array}$ & UCT & Attendance. enrolment \\
\hline $\begin{array}{l}\text { University of } \begin{array}{r}\text { North } \\
\text { Carolina at Chapel } \\
\text { Hill, 2016 }\end{array} \\
\end{array}$ & Malawi & Mixedmethods & $\begin{array}{l}\text { Longitudinal, } \\
\text { experimental } \\
\text { study } \\
\text { design }\end{array}$ & UCT & School participation \\
\hline
\end{tabular}




\section{EFFECT OF CASH TRANSFER PROGRAMMES}

\section{SCHOOL ATTENDANCE}

Of the ten studies we reviewed, eight examined the relationship between cash transfers and school attendance (Akresh, de Walque, \& Kazianga, 2013; Barrera-Osorio, Bertrand, Linden, \& Perez-Calle, 2008; Benhassine, Devoto, Duflo, Dupas, \&Pouliquen, 2015; Ham, 2014; Ribas, Soares, Teixeira, Silva, \& Hirata, 2011; Schaffland, 2012; UNICEF, 2017; University of North Carolina at Chapel Hill, 2016). In Brazil, cash transfers to children in poor households made them missed school slightly more than average (around 0.1 days) in 2004 and 2006 (Schaffland, 2012). When the result was compared with the comparison group, cash transfers were projected to have a positive impact on school attendance of 0.35 fewer days the children missed school in 2004, and approximately 0.32 fewer days in 2006 . Nevertheless, the results did not show significant differences in attendance over time (Schaffland, 2012). In Burkina Faso, data from a two-year cash transfer programmes showed that both CCT and UCT had an impact on school participation (Akresh et al., 2013). At the round three of the programme implementation, CCT increased attendance for all children and those in sub-group (Akresh et al., 2013). Also, UCT increased the attendance for boys and older children. In the comparison of the two social programmes, CCT was discovered to be better in terms of outcome than UCT (Akresh et al., 2013).

A randomised experiment in Columbia revealed that children that received cash transfers (basic and saving treatments) through their households improved school attendance by 3.3 and 2.8 percentage points in the San Cristobal area (Barrera-Osorio et al., 2008). While the transfers increased attendance for all school grades, there was no impact of the basic transfers in the Suba area (Barrera-Osorio et al., 2008). Three cash transfer programmes were investigated for their impact on school outcomes in rural areas: Honduras' Programa de Asignación Familiar (PRAF), Mexico's Programa de Educación, Salud y Alimentación(PROGRESA), and Nicaragua's Red de Protección Social (RPS) (Ham, 2014). The empirical evaluation of these programmes statistically suggested that the programmes in Mexico and Nicaragua significantly increased school attendance while there was no impact of the programme in Honduras (Ham, 2014).
The Malawi Social Cash Transfer Programme has proven that cash transfers have a substantial beneficial impact on attendance among poorer and bigger households (the University of North Carolina at Chapel Hill, 2016). The results of the endline impact evaluation showed that attendance among treatment children were 9 and 13 percentage points, respectively. For secondary school students, school attendance increased by 13 percentage points while that of primary school pupils increased by eight percentage points without school interruptions. For pre-school-aged children, there was no statistically significant impact on attendance. However, there was a positive impact on attendance (the University of North Carolina at Chapel Hill, 2016).

In Morocco, an RCT on the impact of cash transfers on school participation showed that Tayssir cash transfer programme made children from treatment households, $60 \%$ more likely to have attended school (Benhassine et al., 2015). Children in households receiving cash transfers spent more extra time on school-related activities daily compared to 2.5 hours spent by children in households not receiving cash transfers. Furthermore, children receiving cash transfers had more time learning and more time present at the schools as well as more time travelling to and from school (Benhassine et al., 2015). While they spent more time studying, this was not as a result of the abandonment of domestic work; instead they had spare time to invest in education (Benhassine et al., 2015).

In Nigeria, an impact evaluation by UNICEF on Girls Education Project in Niger, and Sokoto States showed impressive results of the impact of the UCT programme (UNICEF, 2017). The quasiexperimental design of the impact evaluation revealed that the cash transfer programme helped in decreasing financial obstacles to girls' attendance at school. The evidence was supported by caregivers interviewed in the two States who confirmed that cash transfers significantly improved girls' school attendance (UNICEF, 2017).

In Paraguay, aside from the positive impact of cash transfers on health outcomes, the Average Treatment Effect (ATT) estimate given by the difference-in-differences methods showed that the conditions attached to the cash transfers increased school attendance in 2006 by $7 \%$ (Ribas et al., 2011). 


\section{SCHOOL ENROLMENT}

The evidence linking cash transfer programmes to improvements in school enrolment was reported by nine studies (Akresh et al., 2013; Barrera-Osorio et al., 2008; Benhassine et al., 2015; Ham, 2014; Handa et al., 2015; Ribas et al., 2011; Schaffland, 2012; UNICEF, 2017; University of North Carolina at Chapel Hill, 2016). In African countries of Burkina Faso, Morocco and Nigeria, three studies found significant positive impacts of cash transfers on school enrolment (Akresh et al., 2013; Benhassine et al., 2015; UNICEF, 2017). However, the impact of Morocco programme was significant but small. Two other studies, one in Kenya found an increase in school enrolment for girls due to the cash transfers, reduced the likelihood of the beneficiary girls having unwanted pregnancy (Handa et al., 2015). Furthermore, the other study in Malawi found substantial impacts of cash transfers on school participation across all age ranges with enrolment as one of the elements of school participation (the University of North Carolina at Chapel Hill, 2016).

In Latin America, three studies found a significant positive impact of cash transfer programmes on school enrolment in Brazil, Columbia and Ecuador (Barrera-Osorio et al., 2008; Paredes, 2017; Schaffland, 2012). Despite a positive and significant impact in Brazil, a decrease in the impact was noticed. While in Columbia, a significant impact of cash transfers was found on Suba, there was no significant impact in San Cristobal. Initially, in Ecuador, the cash transfer programme did not show any impact because the programme did not get to all households that were eligible for cash transfers. However, with the spread of the programme, school enrolment increased for all groups with significant impact for 17, 18- and 20-years old groups but decreased for 19 years old. The only study that evaluated three cash transfer programmes found that cash transfers increased enrolment, especially for disadvantaged children than the advantaged group (Ham, 2014).

Table 2: Review of effects of cash transfer programmes on children's school enrolment

\begin{tabular}{|c|c|c|}
\hline Country & Study & Results \\
\hline Brazil & Schaffland, (2012) & $\begin{array}{l}\text { CCTs had an impact on enrolment with a } 4.5 \% \text { higher probability of } \\
\text { being enrolled for treatment children in } 2004 \text { and } 2006 \text {. Enrolment still } \\
\text { dropped for treatment children over time by } 1.18 \%\end{array}$ \\
\hline Burkina Faso & Akresh et al. 2013 & $\begin{array}{l}\text { CCT did not increase enrolment in the first year but had a positive } \\
\text { impact on enrolment in the following year. For UCT, the impact was } \\
\text { limited and not statistically significant }\end{array}$ \\
\hline Columbia & $\begin{array}{l}\text { (Barrera-Osorio et } \\
\text { al., 2008) }\end{array}$ & $\begin{array}{l}\text { Savings treatment increased enrolment by } 4.3 \text { percentage points while } \\
\text { tertiary treatment boost enrolment by } 4.8 \text { percentage points }\end{array}$ \\
\hline Ecuador & Paredes, 2016 & $\begin{array}{l}\text { Phase 1: Enrolment increased by } 8.7,8.3 \text {, and } 11 \text { percentage points } \\
\text { for } 17,18 \text {, and } 20 \text { years olds respectively. Phase } 2 \text { : Enrolment } \\
\text { decrease significantly by } 23 \text { percentage points for } 19 \text { years old }\end{array}$ \\
\hline Kenya & Handa et al. 2016 & $\begin{array}{l}\text { Cash transfers reduced unwanted pregnancy by five percentage points } \\
\text { which worked through increasing enrolment }\end{array}$ \\
\hline $\begin{array}{l}\text { Latin America } \\
\text { (Honduras, } \\
\text { Mexico and } \\
\text { Nicaragua) }\end{array}$ & Ham, 2014 & $\begin{array}{l}\text { Girls, ethnic minorities, and children from less educated background } \\
\text { benefited from the Mexico and Nicaragua in terms of enrolment with no } \\
\text { impact in Honduras }\end{array}$ \\
\hline Malawi & $\begin{array}{l}\text { University of North } \\
\text { Carolina at } \\
\text { Chapel Hill, } 2016\end{array}$ & Cash transfers had strong effect on enrolment \\
\hline Morocco & $\begin{array}{l}\text { Benhassine et al. } \\
2015\end{array}$ & $\begin{array}{l}\text { Children of cash transfer household approximately } 60 \% \text { more likely to } \\
\text { have attended school }\end{array}$ \\
\hline Nigeria & UNICEL, 2017 & $\begin{array}{l}\text { Cash transfers led to an enrolment increase of } 52 \text { girls per programme } \\
\text { school in Niger State and programme impact of } 29.4 \% \text {; and in Sokoto } \\
\text { State, it was an increase of } 73 \text { girls per programme school and } \\
\text { programme impact of } 32.37 \%\end{array}$ \\
\hline
\end{tabular}

\section{HETEROGENEOUS IMPACTS}

Aside from the impact of cash transfers on school attendance and enrolment, most of the included studies reported various effects of cash transfers.
For instance, about four studies reported the link between cash transfers and academic performance (Akresh et al., 2013; Barrera-Osorio et al., 2008; Benhassine et al., 2015; the 
University of North Carolina at Chapel Hill, 2016). In Burkina Faso, the impact of cash transfers was limited because there was no positive impact on grades or achievement tests (Akresh et al., 2013). In Columbia, there was no significant effect, but cash transfers increased the time spent on homework by half (Barrera-Osorio et al., 2008). In Morocco, a study by Benhassine et al. (2015) found a modest positive impact of cash transfers to fathers on test scores of their children, but the effect was not statistically significant in all the groups. A study in Malawi did not find a strong impact of cash transfers on grade progression (the University of North Carolina at Chapel Hill 2016).

Only five impact assessments of cash transfer programmes in five countries have included graduation, completion, progression and school dropout on the beneficiary children. They were in Columbia (Barrera-Osorio et al., 2008); Ecuador (Paredes, 2017); Morocco (Benhassine et al., 2015); Paraguay (Ribas et al., 2011); and Malawi (the University of North Carolina at Chapel Hill, 2016). In Columbia and Ecuador, some groups have positive points estimates for graduation (Barrera-Osorio et al., 2008; Ribas et al., 2011). However, in Ecuador, the cash transfer programme showed short-term impacts on high school graduation rates and the possibility of enrolling in a college as well as a negative impact on high school graduation rate among 18 years old (Ribas et al., 2011). Analyses of Morocco's cash transfer programme (Tayssir) showed that the dropout rate decreased drastically (Benhassine et al., 2015).

Further analyses in larger school sample showed that dropout declined more in the cash transfer group than the control group (Benhassine et al., 2015). In Paraguay, the impact evaluation showed an increase in school progression but with no significant effect (Ribas et al., 2011). In Malawi, the impact evaluation showed a decrease in the probability that school children aged 6-17 did not complete the lowest grade of elementary school and a moderate increase in the probability that school pupils completed the lower and middle grades of elementary school (the University of North Carolina at Chapel Hill, 2016). Only a few students in the comparison groups completed post-primary school, which looked similar but not much more visible than treatment groups (the University of North Carolina at Chapel Hill, 2016).

Of the studies reviewed, two examined the impacts of cash transfers on education expenditures (Barrera-Osorio et al., 2008; the
University of North Carolina at Chapel Hill, 2016). In Colombia, cash transfers allowed households to increase spending on academic activities for their children (Barrera-Osorio et al., 2008). More education expenses were focused on children that are likely to go to higher institutions than children that are in lower grades (Barrera-Osorio et al., 2008). In Malawi, the social cash transfer programme led to a contributory rise in education expenditures obtained during the school term, approximately equal to the recorded impact on school attendance (the University of North Carolina at Chapel Hill, 2016).

Cash transfers can "reduce child labour, especially when it is a response to household vulnerability" (Rosati, 2016, p. 1). Cash transfer programmes conditioned on school enrolment and attendance will reduce child labour and increase school participation. Two studies reviewed, reported on the relationship between cash transfers and child labour, one in Colombia (Barrera-Osorio et al., 2008) and the other in Malawi (the University of North Carolina at Chapel Hill, 2016). In Colombia, cash transfers reduced the amount of time spent by students working in order for them to concentrate on academic activities (Barrera-Osorio et al., 2008). On the contrary, in Malawi, it was observed that there was a significant increase in child labour among students receiving cash transfers than the comparison group (the University of North Carolina at Chapel Hill 2016).

\section{CONCLUSION}

This systematic review examined the effect of cash transfer programmes on school outcomes on different social programmes in Africa and Latin America. The findings contribute to the development and scholarly debate on the interface between both concepts by providing additional empirical evidence of these programmes impact by measuring various variables that emanated due to cash transfers.

The findings show that both CCT and UCT programmes seem to have a positive impact on children from poor households. These findings further support the hypothesis that children receiving cash transfers are more likely to attend school regularly, enrol in school and improve in academic activities. Furthermore, the findings of this review suggested that cash transfers are more likely to make children progress to the next grade, graduate, and more likely to enroll in a tertiary institution. One pertinent revelation of the findings of this review is that both CCT and UCT have comparable impacts on school participation 
of children receiving cash transfers; however, CCTs are more effective than UCT in enhancing school participation of disadvantaged children who are likely to avoid school due to financial constraint.

In conclusion, the review has proven that cash transfer programmes enhance school participation of disadvantaged children; however, the impacts of most of these programmes vary. Some programmes have significant effects, and others are less significant and limited effects. While these findings are explanatory, the review encounters some limitations. Firstly, some findings of the included studies were difficult to interpret. Secondly, only English language articles were included in the review, whereas other scientific studies have used other languages, especially in Latin America, to examine the interface between cash transfers and school outcomes. Finally, the impact evaluation of most of the included studies was on short-term impact. Further evaluation is required for the long-term impact on the effects of cash transfer programmes on children's school outcomes.

\section{REFERENCE}

Akresh, R., de Walque, D., and Kazianga, H., 2013. Cash Transfers and Child Schooling: Evidence from a Randomized Evaluation of the Role of Conditionality, 1-49.

Awojobi, O. N., 2018. Cash Transfer Programmes on Children's Outcomes: Evidence from Developing Countries. International Journal of Basic, Applied and Innovative Research, 7(4), 139-150.

Barrera-Osorio, F., Bertrand, M., Linden, L. L., and Perez-Calle, F., 2008. Conditional Cash Transfers in Education: Design Features, Peer and Sibling Effects Evidence from a Randomized Experiment in Colombia. World Bank.

Barrientos, A., 2013. Social Assistance in Developing Countries. Cambridge University Press.

Barrientos, A., and DeJong, J., 2006. Reducing Child Poverty with Cash Transfers: A Sure Thing? Development Policy Review, 24(5), 537-552. https://doi.org/10.1111/j.1467-

7679.2006.00346.x

Benhassine, N., Devoto, F., Duflo, E., Dupas, P., and Pouliquen, V., 2015. Turning a Shove into a Nudge? A "Labeled Cash Transfer" for Education. American Economic Journal: Economic Policy, 7(3), 86-125. https://doi.org/10.1257/pol.20130225.

Child Fund International., 2013. The Effects of Poverty on Education in the United States. Retrieved February 19, 2019, from

https://www.childfund.org/Content/News Detail/2147489206/

de Janvry, A., and Sadoulet, E., 2006. Making Conditional Cash Transfer Programs More Efficient: Designing for Maximum Effect of the Conditionality. The World Bank Economic Review, 20(1), 1-29. https://doi.org/10.1093/wber/lhj002.

DFID., 2011. DFID Cash Transfers Evidence Paper. DFID. Retrieved from http://www.cashlearning.org/downloads/c ash-transfers-literature-review.pdf.

Ham, A., 2014. The Impact of Conditional Cash Transfers on Educational Inequality of Opportunity. Latin American Research Review, 49(3), 153-175. https://doi.org/10.1353/lar.2014.0049.

Handa, S., Peterman, A., Huang, C., Halpern, C., Pettifor, A., and Thirumurthy, H., 2015. Impact of the Kenya Cash Transfer for Orphans and Vulnerable Children on early pregnancy and marriage of adolescent girls. Social Science and Medicine, 141, 36-45. https://doi.org/10.1016/j.socscimed.2015. 07.024.

Hanlon, J., Barrientos, A., and Hulme, D., 2010. Just Give Money to the Poor: The Development Revolution from the Global South. Sterling, VA, USA: Kumarian. Retrieved from http://www.kpbooks.com/Books/BookDet ail.aspx?product $I D=234740$.

Honorati, M., Gentilini, U., and Yemtsov, R. G., 2015. The state of social safety nets 
2015 (Vol. 1). Washington, DC. Retrieved from

http://documents. worldbank.org/curated/en/41 $5491467994645020 /$ pdf/97882-PUB-

REVISED-Box393232B-PUBLIC-DOCDATE6-29-2015-DOI-10-1596978-1-4648-0543-1EPI-1464805431.pdf

Independent Commission for Aid Impact., 2016. The role of cash transfers in reducing poverty and vulnerability Assessing the sustainability of DFID. independent Commission for Aid Impact. Retrieved from https://icai.independent.gov.uk/wpcontent/uploads/The-role-of-cashtransfers-in-reducing-poverty-andvulnerability-Approach-Paper.pdf.

Lagarde, M., Haines, A., and Palmer, N., 2007. Conditional cash transfers for improving uptake of health interventions in low- and middle-income countries: a systematic review. JAMA, 298(16), 1900-1910. https://doi.org/10.1001/jama.298.16.1900

Mihai, M., Ţiţan, E., and Manea, D., 2015. Education and Poverty. Procedia Economics and Finance, 32, 855-860. https://doi.org/10.1016/S2212-5671 (15)01532-4.

Moyo, W., 2013. Causes and Effects of Poverty on Academic Achievements of Rural Secondary School Students: Case OF Tshazi Secondary School in Insia District. International Journal of Asian Social Science, 3(10), 2104-2113.

Paredes, T., 2017. The long-term e $\square$ ects of cash transfers on education and labor market outcomes. Retrieved from https://www.researchgate.net/publication/ 327733152_The_longterm_effects_of_cash_transfers_on_edu cation_and_labor_market_outcomes

Reimers, F., Da Silva, C. D., and Treviño, E., 2006. Where is the "Education" in conditional cash transfers in education? Montreal: UNESCO Institute for Statistics.
Ribas, R. P., Soares, F. V., Teixeira, C., Silva, E., and Hirata, G., 2011. Externality and Behavioural Change Effects of a NonRandomised CCT Programme: Heterogeneous Impact on the Demand for Health and Education. SSRN Electronic Journal. https://doi.org/10.2139/ssrn.1963351

Rosati, F. C., 2016. Can cash transfers reduce child labor? IZA World of Labor, 1-10. https://doi.org/10.15185/izawol.293.

Schaffland, E., 2012. Conditional Cash Transfers in Brazil: Treatment Evaluation of the "Bolsa Família" Program on Education.

Slater, R., and Overseas Development Institute. 2008. Cash Transfers, Social Protection and Poverty Reduction. Geneva, Switzerland: United Nations Research Institute for Social Development (UNRISD).

UNICEF. 2017. Impact Evaluation OF UNICEF Nigeria Girls' Education Project Phase 3 (GEP3) Cash Transfer Programme (CTP) in Niger and Sokoto States. UNICEF.

UNICEF-ESARO/Transfer Project., 2015. Social Cash Transfers and Children's Outcomes: A Review of Evidence from Africa. UNICEF. Retrieved from https://www.unicef.org/esaro/Social_Cas $h$ Transfer Publication_ESARO Décem ber_2015.pdf

University of North Carolina at Chapel Hill., 2016. Malawi Social Cash Transfer Programme Endline Impact Evaluation Report. University

of North Carolina at Chapel Hill.

Wikeley, F., Bullock, K., Muschamp, Y., and Ridge, T., 2007. Educational outside school. York: Joseph Rowntree Foundation. Retrieved from http://www.jrf.org.uk/bookshop/eBooks/2 027-education-poverty-activities.pdf.

World Bank., 2011. Safety Nets and Transfers Cash Transfers. Retrieved February 23, 2019, from http://web.worldbank.org/archive/website 01506/WEB/0 CO-28.HTM. 